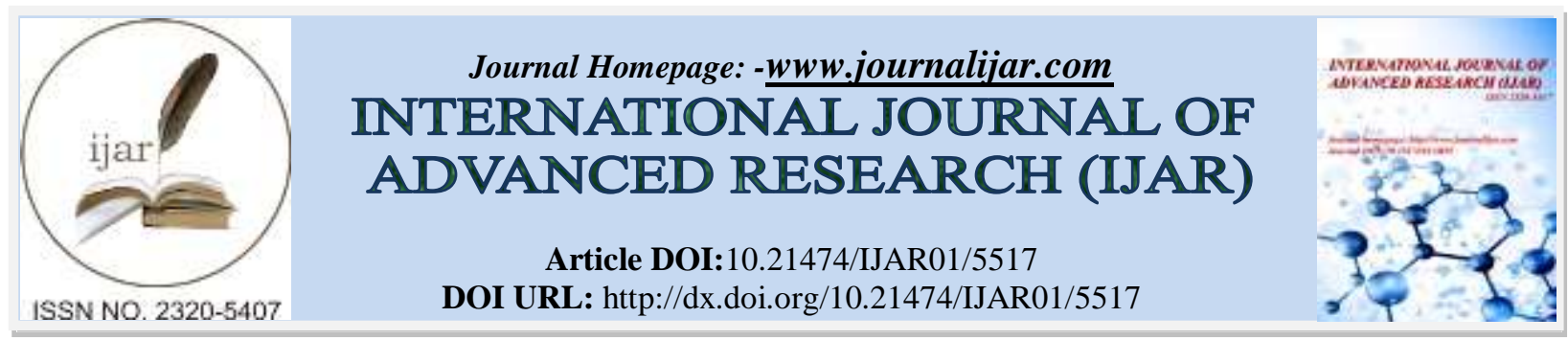

RESEARCH ARTICLE

\title{
THE ANALYSIS OF RESEARCHS AND TEACHERS RESPONSE ABOUT SCIENTIFIC LITERACY AS THE BASIS OF DEVELOPING A COMPUTER-BASED PHYSICS LITERACY TEST.
}

\author{
Restasa Britan Pradhana, Indrawati, Sudarti, and Sutarto \\ University of Jember, Jember, Indonesia.
}

\section{Manuscript Info}

Manuscript History

Received: 02 August 2017

Final Accepted: 04 September 2017

Published: October 2017

Key words:-

Scientific Literacy,

Physics Literacy, and

Computer based Test.

\begin{abstract}
Scientific literacy ability is required as in line with technology progression for the improvement of knowledge. Quality of scientific literacy for countries in the world is known by PISA to evaluate the education for students at the ages of 15. Except PISA, many scientific literacy researches were already developed in Indonesia, but they were not balance for each education levels. This research was to study scientific literacy research by journals and analyze the result of physics teacher's questioner about the physics literacy of senior high schoolstudents. Based on the analysis, researches about scientific literacy in senior high school were not found as many as in junior level, especially for Physics subject. Because Indonesians National Examination is computer-based test, so it needed a trial for student to do the test by using computer. Therefore, researcher needs an instrument developed to investigate the physics literacy of students with a computer-based test.
\end{abstract}

Copy Right, IJAR, 2017,. All rights reserved.

\section{Introduction:-}

The ways of thinking of every student has its own ability in facing a certain problem. It is related to the students' ability in using their own concept in process of making decision and concluding contextually or based on the scientific facts. The ability of students' thinking in solving the problems can be known based on level of scientific literacy or science literacy. Science Literacy, according to Sudiatmika (2010), means the ability in using the knowledge of science, identifying the problems, and making conclusion based on facts in order to comprehend and make decision about nature and its change trough human activity. According to Rannikmae (2009), the ability of science literacy consists of four categories, they are: 1) nominal literacy; 2) functional literacy; 3) procedural/conceptual literacy; and 4) multidimensional literacy. Therefore, to find out the ability level of students' science literacy, the instrument used to evaluate the science literacy ability of students is much needed.

The awareness of the importance of science literacy ability in education makes many countries such as America, Taiwan, China, Hong Kong, Australia, Germany and Chile endeavor to improve its citizen's ability from early age, moreover, it is also done by developing country such as Nigeria (Ojimba, 2013). The quality of science literacy from many countries around the world can be known trough PISA or Programme for International Student Assessment, which is the students' ability evaluation program established by OECD (Organization for Economic Co-operation and Development) for students in the age of 15. Several Indonesian researchers have developed model, teaching material, or other learning tools for materials of Science to improve students' science literacy ability, yet the 
researches much done only for junior high school students. Therefore, the researcher of this scientific article believes that he needs to develop test of science literacy ability for senior high school students.

Along with the education development in this digital era and the application of curriculum of 2013 at several schools and regions, then the form of the evaluation has also experienced transformation become National Examination Computer-Based. To support that matter, the researcher also believes that it is a need to develop a test of science literacy ability especially Physics in the form of computer application software. Based on the previous explanation, the researcher chooses an alternative solution to develop a computer-based instrument of literacy ability test of Physics for senior high school students. Therefore, the researcher needs to study the previous researches about science literacy especially for Physics as well as interview, give out the questionnaires towards Physics teachers, and needs to study the researches that support the development of computer-based physics literacy test.

\section{Purpose of the study:-}

Based on those explanations, purpose ofthe study from this scientific article is to describe the study of the computerbased physics literacy test's development.

\section{Research Method:-}

Data collection technique used is descriptive analysis. The analysis is done towards the previous researches through analysis of science literacy journals that have ISSN, and by doing interview and filling out the questionnaire in the form of question draft answered by 20 Physics teachers about their knowledge about science literacy. It is about whether or not they have ever done research about science literacy towards senior high school students especially for Physics subject, how the result of studying Physics of the students compared to other subjects is, and how their opinions about science literacy in Physics being called as Physics literacy is. In addition, the researcher also studies the literatures that support computer-based test.

The research was done during November 2016, with 20 physics teachers as participants. The selection of participants was done randomly then the descriptive analysis was done as the basic of developing learning model that was needed. The participants' experiences in teaching are in Table 1.

Tabel 1:-Participants Teaching Experience in Years

\begin{tabular}{|l|l|l|}
\hline No. & Teaching Experience & Total \\
\hline 1. & $0-5$ years & 3 \\
\hline 2. & $6-10$ years & 7 \\
\hline 3. & $11-15$ years & 3 \\
\hline 4. & $16-20$ years & 4 \\
\hline 5. & More than 20 years & 3 \\
\hline
\end{tabular}

The difference of experiences in teaching shows that whether or not there is difference of knowledge of the teachers about science literacy ability based on how many years they have been teaching.

\section{Research Findings and Discussion:-}

Science literacy according to De Boer (2000) is a science comprehension and its application at experience in society. Specifically, it is one's ability in using concept, process, and science value in making daily decision as the result of interaction between human and their environment, and comprehending the relevance among science, technology, and various facts that happen in society including the development of social and economy. The science literacy ability now becomes of the important knowledge to develop for students as the next generation of the nation. The developed countries have made serious efforts to optimize this ability. However, it is different from Indonesia having less interest to develop the students' science literacy thoroughly. It is known from the socialization about the importance of this knowledge is not widespread in Indonesia. Therefore, the researcher tries to study the research object from several journals used as samples. Several science literacy journals that have ISSN easily downloaded can be seen at Table 2 .

Tabel 2:-Distribution of Scientific Literacy Research Journals Sample

\begin{tabular}{|c|l|l|l|}
\hline No. & Title & ISSN & Level \\
\hline 1. & $\begin{array}{l}\text { Developing Multiple Choice Test Based on Scientific Literacy } \\
\text { Theme of Auditory and Sonar System in Living Things Grade VIII } \\
\text { in SMP N 1 Wates }\end{array}$ & Junior \\
\hline
\end{tabular}




\begin{tabular}{|c|l|l|l|}
\hline 2. & $\begin{array}{l}\text { Scientific Literacy Profile of First Level Students in Integrated } \\
\text { Science Learning for Environment Pollution Topic }\end{array}$ & $2339-0654$ & Junior \\
\hline 3. & $\begin{array}{l}\text { Developing Scientific Literacy based Multimedia Learning for First } \\
\text { Level Students in Technology Theme }\end{array}$ & $1979-7281$ & Junior \\
\hline 4. & $\begin{array}{l}\text { Development of Scientific Literacy Instrument Test for Junior High } \\
\text { School Student in The Context of Balinese Culture }\end{array}$ & $2087-0523$ & Junior \\
\hline 5. & $\begin{array}{l}\text { Profile of Student Scientific Literacy Improvement by Scientific } \\
\text { Learning }\end{array}$ & $2303-1832$ & Junior \\
\hline 6. & $\begin{array}{l}\text { Analizing Scientific Literacy Ability in Scientific Knowledge and } \\
\text { Competence for Junior High School Student in Heat Matter }\end{array}$ & Junior \\
\hline 7. & $\begin{array}{l}\text { The Use of Scientific Literacy Taxonomy for Assessing The } \\
\text { Development of Chemical Literacy Among High-School Students }\end{array}$ \\
\hline 8. & $\begin{array}{l}\text { Development and Validation of Scientific Literacy Achievement } \\
\text { Test to Assess Senior Secondary School Students Literacy } \\
\text { Acquisition in Physics }\end{array}$ & Senior \\
\hline 9. & $\begin{array}{l}\text { Scientific Literacy Analize for XI Science Grade Student in 222-1735 } \\
\text { Chemistry Basic Law at South of Jakarta }\end{array}$ & Senior \\
\hline
\end{tabular}

The journals above show that the total of research in science literacy is dominated by researches in junior school level. The journals of science literacy researches in junior school students are very easy to find, meanwhile the journals of science literacy researches in senior schools level are still little. The journals of science literacy in Physics are fewer than in Chemistry. As like its name, science literacy ability draws more attention of the researchers whose participant are teachers and junior high school students. It is because in Indonesia, science is identic with Science subject in junior high school level. Meanwhile, there are only few of senior high school teachers, who know and do research about science literacy. The interview and the result of questionnaire filled out by the teachers can strengthen the data as the result of research object of the journals. Questionnaires are answered by 20 Physics teachers with different teaching experience. The result of questionnaire from the participants can be simplified as in Table 3 as follows:

Tabel 3:-Physics Teachers Interview Result

\begin{tabular}{|c|c|c|c|c|}
\hline No & Variables & Answer & Total & $(\%)$ \\
\hline \multirow[t]{2}{*}{1} & \multirow[t]{2}{*}{ Knowledge of Scientific Literacy } & Known & 16 & 80 \\
\hline & & Unknown & 4 & 20 \\
\hline \multirow[t]{2}{*}{2} & \multirow{2}{*}{$\begin{array}{l}\text { Doing science literacy research at senior high } \\
\text { school students }\end{array}$} & Ever & 0 & 0 \\
\hline & & Never & 20 & 100 \\
\hline \multirow[t]{2}{*}{3} & \multirow{2}{*}{$\begin{array}{l}\text { Doing teaching and learning to optimize science } \\
\text { literacy of students }\end{array}$} & Ever & 0 & 0 \\
\hline & & Never & 100 & 100 \\
\hline \multirow[b]{2}{*}{4} & \multirow{2}{*}{$\begin{array}{l}\text { Result of study of Physics under average of the } \\
\text { other Science subjects }\end{array}$} & Yes & 14 & 70 \\
\hline & & No & 6 & 30 \\
\hline \multirow[t]{2}{*}{5} & \multirow{2}{*}{$\begin{array}{l}\text { Measuring the science literacy level of the } \\
\text { students in Physics subject }\end{array}$} & Ever & 0 & 0 \\
\hline & & Never & 100 & 100 \\
\hline \multirow[t]{2}{*}{6} & \multirow{2}{*}{$\begin{array}{l}\text { Opinion about whether or not science literacy in } \\
\text { Physics being called as Physics literacy }\end{array}$} & Agree & 18 & 90 \\
\hline & & Disagree & 2 & 10 \\
\hline
\end{tabular}

Based on the data given above, it is known that only a little of senior high school teachers have knowledge about science literacy, that is only $20 \%$. Not having many experiences in teaching has an effect on the knowledge about science literacy. The data shows that Physics teachers have never applied leaning with the objective to optimize the science literacy ability of the students. This means that teachers with teaching experiences more than 20 years have also never deepened and never evaluated the science literacy ability of the students, especially in Physics subject. This may happen because the education researchers besides teachers do research about science literacy in senior high school. Nevertheless, since the total researches about the importance of science literacy are only a little and the results are less publicized towards Physics teachers, thus the knowledge of Physic teachers about that matter are still minimal. 
The result of the questionnaire also shows that the result of students' study result in Physics according 70\% teachers is lower than any other science subjects. This should become the evaluation in itself by teachers and practitioner to realize the strength and the weakness of each student in Physics subject. Students still have difficulty in understanding Physics material, therefore, the result of the study are less satisfying. The ability of each student is of course different to one-another, but it is certain that they had one ability to direct to. Government started to realize that students can not be burdened with so many subjects to study and master in to determine the graduation. Hence, starting from the year of 2017, the National Examination in Indonesia only examines three compulsory subjects and one optional subject chosen by students based on their own skill. To direct students, teachers need to understand how students' science literacy is, especially in Physics that is still considerate as difficult subject by students. Physics teachers need to understand where students find it difficult and understand the students' ability in incorporating the knowledge concept to solve the problems. This is purposed to understand the students' weakness and strength in Physics subject so that they can improve or even decide the subject that can be chosen by students in National Examination. To facilitate teachers measure students' physics literacy, thus the existence of test arranged especially to measure it, will be very helpful.

Student science literacy can be measured through a test arranged contextually and having different difficulty level in accordance with the total of concept used in each question. The levels of science literacy according to Soobard\&Rannikmäe (2011) are divided into:

a. Nominal Literacy:

Students agree with other people's statement without giving out their own ideas. Students use/benefitted and write scientific terms, but they are not capable of justifying the terms or they miss concept it.

b. Functional Literacy:

Students are able to remember information from textbooks such as writing down the basic facts, but they are not able to justify their own opinions based on the text or graphics given to them. Students even know the concept among the fields, but they are not able to describe the correlation among those concepts.

c. Conceptual/Procedural Literacy:

Students make the use of benefit of the concepts among those fields, and they indicate comprehension and relevance. Students have understanding about the problems, justify the answer correctly information from text, graphic, or table. Students are able to analyze the alternative solution.

d. Multidimensional Literacy:

Students make the use of benefit of various concepts and show the ability to relate those concepts with daily life. Students understand how science, society, and technology fitted together and affect one to another.

Each of these indicators according to Shwartz (2006) can be described as follows:

a. Nominal scientific literacy: Students recognize a concept as related to science, but the level of understanding clearly indicates misconceptions.

b. Functional scientific literacy: Students can describe a concept correctly, but have a limited understanding of it.

c. Conceptual scientific literacy: Students develop some understanding of the major conceptual schemes of a discipline and relate those schemes to their general understanding of science. Procedural abilities and understanding of the processes of scientific inquiry and technological design are also included in this level of literacy.

d. Multidimensional scientific literacy: This perspective of scientific literacy incorporates an understanding of science that extends beyond the concepts of scientific disciplines and procedures of scientific investigation. It includes philosophical, historical, and social dimensions of science and technology. Here students develop some understanding and appreciation of science and technology regarding its relationship to their daily lives. More specifically, they begin to make connections within scientific disciplines, and between science, technology, and the larger issues challenging society.

The researcher assumes that the term of science literacy needs to be specialized in order to make teachers and other researchers having more interest in order to develop the science literacy ability in certain subjects to have more improvement. Therefore, the researcher calls this science literacy in Physics as physics literacy. This is supported by 90\% participants Physics teachers who agree with physics literacy as the term used for science literacy in Physics. Based on the definition of science literation fitted with, thus it can be concluded that physics literacy is an awareness 
of understanding and application of the concept in accordance with the law and theory of physics in the process of describing, identifying, predicting, evaluating, and making decision in solving the matters of nature phenomena and daily event scientifically.

The result of the study in above and the importance science literacy especially in Physics subject for senior high school students, makes the researcher needs to develop measurement of physics literacy test. Physics literacy test is developed like questions applied in PISA with several types such as multiple choice, True-False, matching the answers, and short essay answer. The questions developed consist of four level literacies arranged randomly and contextually. To make it easier for the students, the researcher developed physics literacy test in the form of flash application, thus they need computer to do the test. It is accord with the type of National Examination in Indonesia, which is computer-based test. The development of measurement of computer-based physics literacy test is expected to be able to train students using computer in UNBK. According to Bagus (2012), a computer-based test is more efficient and it has significant positive correlation with a paper-pencil test. Despite of computer-based test just like UNBK, physics literacy test is developed in the form of offline, so it does not need internet connection in doing it. It is explained by Pakpahan (2016) who states that computer-based examination can be done offline or online. Besides to support UNBK, education media in foreign countries have develop various web about learning to improve science literacy ability. This was stated by Okada (2013) who explained that there have been provided various software, web, and application to support learning with emphasizing science literacy. Therefore, the development of measurement of computer-based physics literacy ability is very needed in this digital era.

Thus review about the result of study towards research object from science literacy journals, result of questionnaire from Physics teachers about science literacy, and the result of literature study about computer-based test used by the researcher as the basis in developing computer-based physics literacy test.

\section{Conclusions And Suggestion:-}

Based on the result of the study towards science literacy research journals, the total of research about science literacy ability done at senior high school students are fewer than junior high school students.

The results of interview and questionnaire show that there only little physics teachers who know about science literacy. The difference of teaching experience does not affect the knowledge of physics teachers about science literacy ability because all teacher have never measured and applied learning to improve science literacy especially in Physics subject. The average of students' result of study in Physics subject is still lower compared to other science subjects. Therefore, teachers need to know students' weakness and strength in Physics subjects through physics literacy measurement. This can help teacher to direct students to decide optional subject examined in National examination especially physics. Scientific literacy in Indonesia is identic with science subjects for junior high school students, thus, based on the participants' opinion (Physics teachers), science literacy in Physics subject called as Physics literacy. Besides measuring students' physics literacy, the development of the test can also train students to do test using computer for the preparation of UNBK. The studies that have been explained by researcher are the basic in developing computer-based physics literacy test.

Computer-based physics literacy test developed by the researcher can be doubled and applied by teachers and other researchers to do research towards physics literacy ability of senior high school students. Thus, the result can be used as the guidance in evaluating, correcting, and improving the quality of physics literacy (as the part of science literacy) of the students as the next generation of the nation.

\section{References:-}

1. Adeleke, A.A. et al. 2015. Development and Validation of Scientific Literacy Achievement Test to Assess Senior Secondary School Students' Literacy Acquisition in Physics.Journal of Education and Practice.6 (7). 28 - 42. ISSN: 2222-1735.

2. Asyari, A. et al. 2015. Profile of Student Scientific Literacy Improvement by Scientific Learning.JurnallmiahPendidikanFisika 'Al-Biruni'. 4(2). 179 - 191. ISSN: 2303-1832.

3. Ardiansyah, A. et al. 2016. Scientific Literacy Analize for XI Science Grade Student in Chemistry Basic Law at South of Jakarta. Jurnal Kimia danPendidikan.1 (2). ISSN:2502-4787.

4. Bagus, H.C. 2012. AdministrasiUjianNasional (UN) denganMenggunakan Model Computerizad Adaptive Testing (CAT).JurnalPendidikandanKebudayaan. XVIII (1) 45 - 53. 
5. Deboer, G.E. 2000. Scientific Literacy: Another Look at Its Historical and Contemporary Meanings and Its Relationship to Science Education Reform.Journal of Research in Science Teaching.

6. Ilma, M.N. 2015.Developing Multiple Choice Test Based on Scientific Literacy Theme of Auditory and Sonar System in Living Things Grade VIII in SMP N 1 Wates. JurnalPendidikan IPA. 1 - 7. ISSN: 2089-4392.

7. Latip, A. et al. 2015. Developing Scientific Literacy based Multimedia Learning for First Level Students in Technology Theme. EDUSAINS.7 (2). 160 - 171. ISSN: 1979-7281.

8. Mawardini, A. et al. 2015. Scientific Literacy Profile of First Level Students in Integrated Science Learning for Environment Pollution Topic.E-Journal prosiding seminar nasionalfisika.IV. 49 - 55. ISSN: 2339 - 0654.

9. Ojimba. 2013. Scientific and Technological Literacy in Africa: Issues, Problems and Prospects' Dimensions (Ipp). Educational Research International.II(1).

10. Okada, A. 2013. Scientific Literacy in The Digital Age: Tools, Environments and Resources for Co-Inquiry. European Scientific Journal, IV pp. 263-274. ISSN: 1857 - 7881

11. Pakpahan, R. 2016. Model UjianNasionalBerbasisKomputer: ManfaatdanTantangan. JurnalPendidikandanKebudayaan. I (1) 19 - 35.

12. Rannikmae, M. (2009). The Meaning of Scientific Literacy.International Journal of Environmental \& Science ducation. 275-276.

13. Shwartz, Y. et al. 2006. The Use of Scientific Literacy Taxonomy for Assessing The Development of Chemical Literacy Among High-School Students. Chemistry Education Research and Practice.7 (4). ISSN:1756-1108.

14. Soobard, R., \&Rannikmäe, M. 2011. Assessing student's level of scientific literacy using interdisciplinary scenarios .Science Education International, 133-144.

15. Sudiatmika, R. 2010. PengembanganAlatUkurTesLiterasiSainsSiswa SMP dalamKonteksBudaya Bali.UniversitasPendidikanIndonesia :Disertasi

16. Wulandari, N. 2016.Analisis Kemampuan LiterasiSainsPadaAspekPengetahuan Dan KompetensiSainsSiswaSmpPadaMateriKalor. Edusains, VIII (1), 66-73. ISSN 1979-7281. 